\title{
Funding Sources for Research and Scholarship
}

\author{
Fazil T. Najafi
}

University of Florida

\begin{abstract}
A direct lead between existing research funding needs and research funding sources is lacking. This problem creates a burden on the part of science and engineering college professors who must spend excessive time and effort to search and identify a funding source(s) in order to obtain the information necessary for preparing a research proposal. Since writing a research proposal is time and energy intensive itself, it would be very desirable to develop a simple and direct method for obtaining information on potential sources of funding according to the applicant's designated research topic(s). In addition, there are many sources of scholarships/fellowships to which both professors and students should have easy access. Professors also need to be capable of advising students on funding sources and relevant details. Therefore, this paper will focus on these issues and will identify direct research and scholarship sources that enable researchers and students to identify needed sources with minimal time and effort. This paper will also identify existing research sources that provide research funding to civil, environmental, coastal and other science and engineering disciplines.
\end{abstract}

\section{Introduction}

There are many sources of research funding available to support the research work of scientists, engineers, and professors within the institutions of higher learning. Research funding sources are scattered under a variety of subjects, such as health and biomedical sciences, arts, humanities, social sciences and education. Such funding sources also include science and engineering. Many of the existing research funding sources are not listed separately according to discipline. Because of this lack of identity of sources covering particular subjects, the researcher must spend much time and effort searching out the sources that include the subject relating to his/her line of expertise. There are also many sources of fellowships, internships, and scholarships available for both faculty and students. The problem, again, is that these are so scattered, it is difficult to track the appropriate ones from a designated source. This paper will present general information on research sources and will mostly focus on research funding sources for civil engineering faculty who are interested in doing research in the civil engineering and related construction technologies. For the field of civil engineering alone, research funding areas include geotechnical, transportation engineering and planning, land surveying and

Proceedings of the 2001 American Society for Engineering Education Annual Conference \& Exposition Copyright (c) 2001, American Society for Engineering Education 
mapping, materials, structure, water resources, construction engineering and management, coastal engineering and public works engineering infrastructure. Specific civil engineering research subjects include: in situ testing of soils; laboratory instrumentation; soil mechanics; foundations; soil-structure interactions; flow-through porous media and centrifugal modeling; pavement; rock; non-destructive testing; concrete; fiber reinforced polymers; global positioning system; airborne laser swath mapping; geographic information system; computer modeling; video imaging; simulation modeling; safety; signal timing and remote sensing.

\section{Research Sources}

Some funding sources are presented in Table 1. In addition, researchers may contact the American Society of Civil Engineers (ASCE) office in Reston, Virginia, for the ASCE booklets on Highway Technology and Development.

\section{TABLE 1. Funding Source Contact Information}

\begin{tabular}{|c|c|c|c|}
\hline \multicolumn{2}{|r|}{ Source } & \multirow{2}{*}{$\begin{array}{c}\text { Contact, Phone \# } \\
\text { and/or Fax \# }\end{array}$} & \multirow{2}{*}{ E-mail or Website } \\
\hline Acronym & Name & & \\
\hline $\begin{array}{l}\text { AASHTO- } \\
\text { Publications }\end{array}$ & $\begin{array}{l}\text { American Association of State Highway } \\
\text { Transportation Officials-Publications }\end{array}$ & (800) 231-3475 & http://www.aashto.org \\
\hline $\begin{array}{l}\text { ACAA } \\
\text { Education } \\
\text { Foundation }\end{array}$ & $\begin{array}{l}\text { American Coal Ash Association Education } \\
\text { Foundation }\end{array}$ & $\begin{array}{l}\text { Samuel S. Tyson } \\
\text { (703) 317-2400 }\end{array}$ & $\begin{array}{l}\text { ACAA-USA@msn.com } \\
\text { http://www.acaa-usa.org }\end{array}$ \\
\hline ACI & American Concrete Institute International & (248) 848-3700 & http://www.aci-int.org \\
\hline APWA & American Public Works Association & (816) 472-6000 & http://www.pubworks.org \\
\hline $\begin{array}{l}\text { ARTBA- } \\
\text { Directory }\end{array}$ & $\begin{array}{l}\text { American Road and Transportation Builders } \\
\text { Association-Directory }\end{array}$ & (888) 821-9653 & http://www.artba-hq.org \\
\hline ASCE-CERF & $\begin{array}{l}\text { American Society of Civil Engineers/ } \\
\text { Civil Engineering Research Foundation }\end{array}$ & $\begin{array}{l}\text { Peter Kissinger } \\
(202) \text { 842-0555 }\end{array}$ & http://www.cerf.org \\
\hline-- & Chi Epsilon / Tau Beta Pi & $\begin{array}{l}\text { Robert L. Henry } \\
\text { (817) 272-2752 }\end{array}$ & rhenry@utarig.uta.edu \\
\hline \multirow[t]{2}{*}{$\mathrm{CRC}$} & \multirow[t]{2}{*}{$\begin{array}{l}\text { Concrete Research Council } \\
\text { (of ACI) }\end{array}$} & $\begin{array}{l}\text { Dr. Paul Tikalsky } \\
\text { (814) } 863-5844\end{array}$ & TIKALSKY@PSU.EDU \\
\hline & & $\begin{array}{l}\text { David W. Fowler } \\
(512) 471-4498\end{array}$ & dwf@mail.utexas.edu \\
\hline CRSI & Concrete Reinforcing Steel Institute & $\begin{array}{l}\text { David P. Gustafson } \\
\text { (847) 517-1200 (Ext. 13) }\end{array}$ & david@crsi.org \\
\hline-- & United States Army Corps of Engineers & $\begin{array}{l}\text { Tony C. Liu } \\
(202) 761-0222 \\
\end{array}$ & tony.c.liu@usace.army.mil \\
\hline FHWA & Federal Highway Administration & $\begin{array}{l}\text { Steve W. Forster } \\
(202) 493-3070\end{array}$ & steve.forster@fhwa.dot.gov \\
\hline FHWA-NHI & $\begin{array}{l}\text { Federal Highway Administration-National } \\
\text { Highway Institute }\end{array}$ & (703) 235-0500 & http://www.nhi.fhwa.dot.gov \\
\hline IBTTA & $\begin{array}{l}\text { International Bridge, Tunnel \& Turnpike } \\
\text { Association }\end{array}$ & (202) 659-4620 & ibtta@ibtta.org \\
\hline
\end{tabular}

Proceedings of the 2001 American Society for Engineering Education Annual Conference \& Exposition Copyright (C) 2001, American Society for Engineering Education 


\begin{tabular}{|c|c|c|c|}
\hline \multicolumn{2}{|r|}{ Source } & \multirow{2}{*}{$\begin{array}{l}\text { Contact, Phone \# } \\
\text { and/or Fax \# }\end{array}$} & \multirow{2}{*}{ E-mail or Website } \\
\hline Acronym & Name & & \\
\hline IPRF & Innovative Pavement Research Foundation & $\begin{array}{l}\text { Robert J. Betsold } \\
(202) \text { 842-3703 }\end{array}$ & rbelsold@pavement.com \\
\hline IAFD & $\begin{array}{l}\text { International Association of Foundation } \\
\text { Drilling Scholarships }\end{array}$ & $\begin{array}{l}\text { Susan King } \\
(214) \text { 343-2091 }\end{array}$ & adsc@ eaze.net \\
\hline ICRI & International Concrete Repair Institute & (703) 450-0116 & http://www.icri.org \\
\hline IJBRC & $\begin{array}{l}\text { International Joints and Research Council } \\
\text { (of ACI) }\end{array}$ & $\begin{array}{l}\text { Barrie Atkinson } \\
(508) 668-6600\end{array}$ & \\
\hline NACE & $\begin{array}{l}\text { National Association Corrosion Engineers } \\
\text { (NACE International) }\end{array}$ & (281) 228-6100 & http://www.nace.org \\
\hline NCMA & National Concrete Masonry Association & $\begin{array}{l}\text { Mark B. Hogan } \\
(703) 713-1900\end{array}$ & masonryresearch.org \\
\hline NHI & USDOT/FHWA National Highway Institute & $\begin{array}{l}\text { Dr. Moges Ayele } \\
\text { (703) 235-0531 }\end{array}$ & http://www.nhi.fhwa.dot.gov \\
\hline NRMCA/NAA & $\begin{array}{l}\text { National Ready Mix Concrete } \\
\text { Association/National Aggregate Association }\end{array}$ & $\begin{array}{l}\text { Gary M. Mullings } \\
(301) \text { 345-6532 }\end{array}$ & http://www.nationalaggregates.org \\
\hline NSF & National Science Foundation & $\begin{array}{l}\text { Ken P. Chong } \\
(703) 306-1361\end{array}$ & kchong@nsf.gov \\
\hline NSPE & $\begin{array}{l}\text { National Society of Professional Engineers } \\
\text { Professional Engineers in Industry } \\
\text { Scholarships }\end{array}$ & (703) 684-2800 & http://www.nspe.org \\
\hline PCA & Portland Cement Association & $\begin{array}{l}\text { Anthony E. Fiorato } \\
(847) 966-6200\end{array}$ & fiorato@ portcement.org \\
\hline PCI & Prestressed Concrete Institute & $\begin{array}{l}\text { Thomas B. Battles } \\
\text { (312) 786-0300 }\end{array}$ & http://www.pci.org \\
\hline RCRC/NIST & $\begin{array}{l}\text { Reinforced Concrete Research Council (of } \\
\text { ACI)/ } \\
\text { National Institute for Science \& Technology }\end{array}$ & $\begin{array}{l}\text { H. S. Lew } \\
(301) 975-6061\end{array}$ & hsl@nist.gov \\
\hline SBIR & $\begin{array}{l}\text { Small Business Innovative Research (for } \\
\text { USDOT only) }\end{array}$ & $\begin{array}{l}\text { Dr. George Kovatch } \\
(617) \text { 494-2051 }\end{array}$ & http://www.volpe.dot.gov \\
\hline $\mathrm{SC}$ & Scholarship Council (of ACI) & $\begin{array}{l}\text { Bertold E. Weinberg } \\
\text { (518) 439-9469 }\end{array}$ & \\
\hline SDC & $\begin{array}{l}\text { Strategic Development Council } \\
\text { (of ACI) }\end{array}$ & $\begin{array}{l}\text { William H. Plenge } \\
\text { Fax (410) 255-0344 }\end{array}$ & \\
\hline $\begin{array}{l}\text { TRB-NCHRP- } \\
\text { IDEA }\end{array}$ & $\begin{array}{l}\text { Transportation Research Board-National } \\
\text { Cooperative Highway Research Program- } \\
\text { Innovations Deserving Exploratory Analysis }\end{array}$ & $\begin{array}{l}\text { Neil F. Hawks } \\
(202) 334-1430\end{array}$ & http://www.nas.edu/trb \\
\hline
\end{tabular}

Research in water and watershed areas is available on the National Center for Environmental Research and Quality Assurance Web Site at http://es.epa.gov/ncerqa/rfa/washed.html.

Fedix opportunity alert can be found under: alert@riley.fie.com. Another source is COS Funding Alert: funding alert@ cos.com. 
In the June 23, 1997, issue of New Technology Week, the White House's "High-Priority Research Areas" included:

- Large-scale Networking, High End Computing, and Next-Generation Internet

- Building Research

- Transportation Research and Development

- Aviation Safety and Security

- Environmental Monitoring and Research

- Natural Disaster Reduction Research

Another publication that has been published aperiodically by the U. S. Department of Transportation (USDOT) is A Guide to Technology and Innovation (Jan. 2000), 18 pages. It has a list of contacts in each of the agency's ten offices. It can be accessed on the Internet at http://scitech.dot.gov or http://t2.dot.gov.

For a broader approach to federal Research and Development (R\&D), a good reference is The United States Government Manual (yearly) available from the U. S. Government Printing Office. Using this as a starting point, one can search through the telephone numbers to locate someone actually involved in R\&D who can provide meaningful information on the subject of say, "concrete." However, one must be wary since many offices have the word "Research" as part of their title although they are not related to R\&D projects per se. Another approach is to work the buddy network by scanning the ACI directory for members from government agencies (U.S. Army Corps of Engineers or from Federal Highway Administration "FHWA"), such as some of those mentioned in Table 1. There is also an organization of government laboratories that may be consulted. Additionally, there are many branch offices scattered about the country, especially in state capital cities where one can get help in navigating the bureaucracy. More recently, most agencies now have a web page that can direct the potential researcher to the R\&D office of that agency.

Each federal agency has a SBIR (Small Business Innovative Research) program for funding research. In the Department of Transportation (DOT), two and a half percent of R\&D funding is set aside to fund about ten new studies a year. Each agency has its own set of rules and solicitation schedule that are available from the Small Business Administration office listed in the local phone book.

One other program administered through the Transportation Research Board is the Innovations Deserving Exploratory Analysis (IDEA) Program. This program awards funding for about twenty projects each year for up to $\$ 100,000$. Selections are made twice a year. Finally, many agencies are empowered to do collaborative research with industry at a federal laboratory. The U. S. Army Corps of Engineers has conducted a number of studies under these "Cooperative R\&D Agreements (CRADA)." Other projects have been conducted at NIST, Oak Ridge National Laboratory, Los Alamos, etc.

Proceedings of the 2001 American Society for Engineering Education Annual Conference \& Exposition Copyright (C) 2001, American Society for Engineering Education 
The NSF has a broad program of assistance available to university personnel. There are project awards, equipment awards, young presidential researcher awards, travel awards, and they also establish research or science centers, such as the ACBM (Advanced Cement Based Materials) center at Northwestern, and the ATLSS (Advanced Technology for Large Structural Systems) at Lehigh. The researchers at centers like ACBM or ATLSS may consider doing cooperative research with someone submitting a proposal. Additionally, the other departments have their own "centers" situated at various universities: DOT has 33 University Transportation Centers (UTCs) (one is the Infrastructure Institute at Northwestern); the Department of Commerce (DOC) has manufacturing assistance centers; even the National Air and Space Administration (NASA) has Technology Transfer Centers to aid public works; etc.

One last trick to obtaining federal funding is to solicit up to $\$ 5,000$ from several R\&D offices as a jointly funded study that has meaning to the missions of each of the offices. For instance, the FHWA may join with NIST and the U.S. Army Corps of Engineers at \$1,000 each to match funding from ASCE to publish the proceedings of a conference on the durability of concrete.

Despite the availability of the federal funds just described, it is not the best path for most researchers. Often it takes more than a year to get approval and the paperwork can be overwhelming. Additionally, the downsizing of staff has escalated the size of contracts so that the contracts sometimes become an unwieldy collection of different tasks.

\section{Explore Local and State Search}

It is suggested that researchers first look at what assistance is available locally. First, is there "other department funding" in the university? Then, is there a possibility of funding from "other schools or institutes" within the university? Next, is the possibility of collaboration with other universities that may have funding as a technical center for DOT, NSF, etc., such as ACBM.

One then looks toward local businesses: a local quarry operation; a ready mix plant; a precast plant; a power plant (fly ash); a chemical by-products or waste source (admixtures); slag; a paving contractor; an equipment supplier (cutting, grooving, blasting); a cement producer; a local or state agency with a problem (deicing). Examples could be cited of each of the above sources having been used. It takes some tact and forwardness to convince potential sponsors that a particular R\&D project will benefit them.

At the same time, a researcher needs to explore state support. Some states have agencies that fund scientific studies, small businesses, or educational outreach programs. Pennsylvania has Ben Franklin funds that have been used for concrete studies, while Illinois funded educational work on concrete. New York has Sea Grants that were used to study zebra mussel attachments on concrete, and California Sea Grants funded work on tremie placed fly ash concrete.

The State DOT's are the greatest source of R\&D funds. They administer almost $\$ 100$ million of State Planning and Research (SPR) funds that are returned from the FHWA. This is also augmented

Proceedings of the 2001 American Society for Engineering Education Annual Conference \& Exposition Copyright (C) 2001, American Society for Engineering Education 
with the State's own funding. Contact is advised with the local DOT for details on their program. Texas spends about $\$ 15$ million per year on about 100 studies which, by law, must go to Texas A\&M or the University of Texas. Perhaps it is possible to get a staff member from a Texas university to submit a proposal to explore a proposed problem. Both American Road and Transportation Builders Association (ARTBA) and American Association of State Highway \& Transportation Officials (AASHTO) publish yearly directories that list people down to the level of $\mathrm{R} \& \mathrm{D}$, Bridge, and Materials Engineers. Information on the various state SPR programs (and they vary greatly because some states have divested their $R \& D$ outfits to state universities) are available from the FHWA Division offices located in each state capital.

If a proposed project involves a full-scale construction project (prestressed pavement, HPC bridge, etc.), a researcher might seek political endorsement by the State or the governor who might act to help a resident business. For instance, one governor said his state will build experimental aluminum bridge decks (to help develop a nationwide market for a local industry). Other experimental projects can be funded through various programs funded jointly by FHWA and the States. Additionally, some special highway products may be candidates for evaluation under such programs as CERF's Highway Innovative Technology Evaluation Center (HITEC) or AASHTO's comparative testing program NTPEP (National Transportation Product Evaluation Program). NIST, the U.S. Army Corps of Engineers, and other agencies also do some product testing and evaluation.

\section{Private Sources}

According to Athletic Business, July 1999, in an article by Erin Peterson called "Wishes Granted," there are "more than 200,000 grants of \$10,000 or more from 50,000 foundations." Each has its procedures and it is apparently a daunting task to create a successful match. Aids include the Foundation Center web site (www.fdncenter.org) the Catalog of Federal Domestic Assistance, available at libraries or for purchase from the government or accessible at www.gsa.gov/fdac; and a trade group, the American Association of Fund-Raising Counsel, accessible at www.aafre.org.

\section{Fellowships and Scholarships}

Funding for students and faculty summer fellowships and scholarships are available from many sources. They are:

- Honorary societies such as Chi Epsilon and Tau Beta Pi

- American Coal Ash Association Education Foundation (ACAA)

- FHWA National Highway Institute Eisenhower Fellowships of various types (about 40 awards)

- American Society for Civil Engineers (ASCE)

- National Society of Professional Engineers (NSPE) Professional Engineers in Industry 
- The National Aeronautic and Space Administration Faculty Fellowship Program $^{1}$, www.asee.org/fellowship/html/nasa.htm

- The Office of Naval Research Postdoctoral Fellowship Program ${ }^{1}$, www.asee.org/postdoc

- NSF Engineering Research Centers Grants ${ }^{1}$, www.nsf.gov/cgi_bin/getpub?nsf98146

- NSF Professional Opportunities for Women in Research and Education (POWRE) ${ }^{1}$, www.nsf.gov/pubs/1999/nsf99164/nsf99164.html

- Trent R. Dames and William W. Moore Engineering Fellowship ${ }^{1}$, www.asce.org/peta/ed/app_d\&m.html

- Office of Naval Research Summer Faculty Research Program ${ }^{2}$, www.asee.org/summer

- Office of Naval Research Sabbatical Leave Program², www.asee.org/summer

- American Honda Foundation Grants ${ }^{3}$, www.ci.torrance.ca.us/business/05385.html

- NSF, Division of Human Resource Development ${ }^{3}$, www.nsf.gov/pubs/2000/nsf00131/nsf/00131.html

- U.S. Department of Education ${ }^{3}$, OESE_MSAP@ed.gov

- NASA Small Business Innovation Research ${ }^{3}$, http://sbir.gsfc.nasa.gov/SBIR/partintro.htm

- Fannie and John Hertz Foundation ${ }^{3}$, www.hertzfoundation.org

- The Fulbright Scholar Program ${ }^{4}$, www.cies.org

- Sloan Industry Centers Fellowships ${ }^{4}$, www.sloan.org

Here are a few listings of opportunities in international programs:

- $\mathrm{NSF}-$ Conferences and International Travel ${ }^{4}$

- Canadian Embassy - Grant Programs ${ }^{4}$

- Library of Congress Fellowships in International Studies ${ }^{4}$

- NIS College and University Partnership Programs ${ }^{4}$

- Helene Harris Memorial Trust - HHMT Traveling Fellowship ${ }^{4}$

Many scholarships are not widely known. For instance, the International Association of Foundation Drilling (IAFD) has awarded more than 100 fellowships in the past ten years. In 1997, they 
awarded 13 scholarships each for $\$ 2,500$. To find these opportunities, one must search them out in the engineering literature.

One additional source of information on various aspects of recent developments (particularly in transportation/construction technologies) is the system of about 55 Local Technology Assistance Program (LTAP) centers funded by states and FHWA. Each state has an office, usually at one of the universities, to act as a clearing-house. The American Public Works Association (APWA) is FHWA's agent for managing the LTAP clearing-house. They can be used to develop numerous contacts in industry, academia, government and trade organizations.

\section{Conclusion}

Developing research proposals and identifying sources of $R \& D$ funds may seem like an insurmountable obstacle to the novice researcher. A new researcher should explore his/her own institution's resources for research opportunities. In addition to what is presented in this paper, many other sources are available, although it can be a daunting task to search them out. The author has attempted to offer some guidance about how to proceed without being too specific, since each research study is different. In general, it is better to start at the local level and work up to the federal level (or international, which has been briefly addressed in this paper). It is also better to solicit several sponsors to share the costs, act as an advisory panel, and get technically interested in the study. In addition, if the researcher develops a marketable product, the sponsors are there to help bring it to fruition. A final reference is made, once again, to the list of contacts in Table 1. It is important to continuously update sources identified in this paper and add new sources as they become available.

\section{References}

1. Prism. American Society of Engineering Education (ASEE), Washington DC. Vol. 9, No. 6, 32-34, Feb. (2000).

2. Prism. American Society of Engineering Education (ASEE), Washington DC. Vol. 10, No. 3, 32-34, Nov. (2000).

3. Journal of SMET Education: Innovations and Research, Auburn, AL. May-Aug., 16 (2000).

4. Prism. American Society of Engineerng Education (ASEE), Washington DC. Vol. 10, No. 10, 32-34, Oct. (2000).

\section{FAZIL T. NAJAFI}

Dr. Najafi is a tenured professor of civil engineering and Head of the Public Works Program at the University of Florida, Department of Civil and Coastal Engineering. He earned his BSCE from the American College of Engineering, Kabul, Afghanistan, and his BSAE, MS, and PhD degrees in Civil Engineering from Virginia Polytechnic Institute and State University. He has worked for 35 years in government, industry, and education. 
Besides teaching during the last 14 years, Dr. Najafi has conducted research, has been a participating member of several professional societies including ASEE, has published numerous refereed and nonrefereed articles, and has presented many technical papers to international, national and local organizations. 